\title{
The Pattern of Nahdlatul Ulama's Ijtihad
}

\author{
Mustopa Kamal \\ Institut Agama Islam Darussalam (IAID) Ciamis Jawa Barat \\ Email: kamal.bojong@gmail.com \\ Ayi Ishak Sholih Muchtar \\ Institut Agama Islam Darussalam (IAID) Ciamis Jawa Barat
}

\begin{abstract}
ABSTRAK
Sejalan dengan dinamika sosial-keagamaan pada masyarakat, berkembang pula pelbagai masalah di seputar fikih, yang sebagian besar belum terserap dalam pemikiran hukum para ulama. Terhadap masalah-masalah yang biasa disebut dengan masa'il fighiyyah al-haditsah, para ulama sejatinya telah memiliki mekanisme institusional yang digunakan untuk memecahkan problematika tersebut. Nahdlatul Ulama yang merupakan organisasi keagamaan Islam terbesar di Tanah Air juga concern terhadap masa'il fighiyyah al-haditsah melalui mekanisme Bahtsul Masa'il (BM-NU). Namun kerangka istinbath hukum BM-NU ini memiliki keunikan, karena berbeda dengan kerangka istinbath hukum yang dimiliki oleh ulama sebelumnyaseperti kerangka istinbath hukum yang digunakan oleh Abu Hanifah dan Muhammad Ibn Idris al-Syafi'i, juga berbeda dengan kerangka istinbath hukum dengan ormas Islam Indonesia lainnya - seperti kerangka istinbath hukum Dewan Hisbah Persis dan kerangka istinbath hukum Majlis Tarjih dan Pengembangan Pemikiran Islam Muhammadiyah. Keunikan itu terutama karena kerangka istinbath hukum yang dianut oleh BM-NU cenderung menampilkan diri sebagai ulama muttabi dan tidak menampilkan diri sebagai ulama mujtahid sebagaimana secara umum dipahami oleh fuqahâ.
\end{abstract}

\section{ABSTRACT}

In line with the socio-religious dynamics in society, various problems surrounding figh have also developed, most of which have not been absorbed in the legal thinking of the scholars. Concerning issues commonly referred to as masa'il fighiyyah al-hadithah, scholars have institutional mechanisms to solve these problems. Nahdlatul Ulama, the most prominent Islamic religious organization in the country, is also concerned with masa'il fighiyyah al-hadithah through the Bahtsul Masa'il (BM-NU) mechanism. However, the BM-NU legal istinbath framework is unique, because it is different from the legal istinbath framework that previous scholars hadsuch as the legal istinbath framework used by Abu Hanifah and Muhammad 
Ibn Idris al-Syafi'i, also different from the legal istinbath framework with mass organizations. Other Indonesian Islam - such as the legal istinbath framework of the Persis Hisbah Council and the legal istinbath framework of Majlis Tarjih and the Development of Muhammadiyah Islamic Thought. The uniqueness is mainly because the legal istinbath framework adopted by BM$\mathrm{NU}$ tends to present themselves as muttabi' ulama and does not present themselves as mujtahid clerics as is generally understood by fuqahâ.

Keywords: Bahtsul masấ'il, istinbâth, Nahdlatul Ulama, qiyâs, llhâq, mu'tabarah.

\section{INTRODUCTION}

Ijtihad has been carried out by scholars since the time of the Prophet Muhammad. However, the new ijtihad is formulated more clearly and is equipped with a number of important steps that are estimated - based on the literature that can be traced - compiled at the end of the Umayyad era of Damascus and the beginning of the reign of the Bani. Abbas. Practically, ijtihad has been carried out by the Prophet and his great companions. However, the explanation of the definition of ijtihad was only compiled at the time of Abu Hanifah and Shafi'i. Imam Abu Hanifa explained that ijtihad is (بذل الجهد لنيل المقصود). (Al-Dzarwi, 1983: 9). The Imam al-Shafi'i is of the opinion that ijtihad is (بذل الفقيه استنباط الأحكام العملية لتها التفصيلية) (Zahrah, t.th:379). The definition of ijtihad as explained by the Shafi'iyah can be seen in the definition of Imam Al-Ghazali (t.th: 350; 1984: 24; Zahrah, t.th: 109; Mubarok, 1998: 72). Imam Abu Hanifa (80-150 H) offers the following steps for ijtihad: first, he looks for evidence in the Qur'an. Second, if it is not found in the Qur'an, he looks for it in the Sunnah of the Prophet; third, if it is not found in the Qur' an and Sunnah, he seeks the opinion (qawl) of friends; if it is not found in the Qur'an, Sunnah, and qawl companions, he will ijtihad as other tabi'in also perform ijtihad (Mubarok, 2000:74). After that, the steps of ijtihad were developed by scholars in a relatively non-uniform manner (alZuhaili, 1986). The method of ijtihad of mujtahid scholars is preserved in various books of ushul figh which are read by many scholars in various countries, including scholars in Indonesia.

In Indonesia, there are a number of Islamic community organizations (ormas) that have determined the steps in carrying out legal istinbath, including Nahdlatul Ualama. Jaih Mubarok and Nurrohman have conducted research on the methods of ijtihad carried out by Islamic 
organizations in Indonesia (Mubarok, 2002:169). However, this research is only descriptive in nature-haven't analyzed it more sharply. Therefore, this paper is a continuation of this research which is expected to complement previous research. In addition, the analysis is carried out by means of comparison, namely comparison with the ijtihad steps offered by ushul figh experts in various schools of figh.

\section{METHOD}

This study uses a literature review method or literature review. In this study, a literature review was used to survey scientific sources on the ijtihad pattern of Nahdlatul Ulama, the oldest Islamic religious organization in Indonesia, to provide an overview of the current development of the Nahdlatul Ulama ijtihad pattern.

\section{RESEARCH RESULTS AND DISCUSSION}

\section{Al-Qur'an and Hadith as Sources of Law}

In general, scholars are of the opinion that the highest source $(a s h l)$ of law is the Qur'an; Sunnah is used as the second source; and ijtihad is used as the third source of law (Dawud, t.th.: 303; Mubarok, 2002:7; Khallaf, t.th.: 21). The exception to this general opinion is the opinion of al-Qadhi 'Abd alJabbar. He argues that the highest source of law is reason $\left(a l-r a^{\prime} y\right)$, and the next source of law is the Qur'an, Sunnah, and ijma' (Al-Hamadani, 1965:88). Jaih Mubarok - trying to harmonize the two opinions by saying that the sources of Islamic law are the Qur'an, Sunnah, and ijtihad - without showing a hierarchy; but cumulative; because-explained Jaih Mubarok - the Qur'an and Hadith which are used as the highest sources of law are basically understood by means of ijtihad, at least, by means of ijtihad bayani (Mubarok, 2002:8).

In contrast to the opinion of scholars in general, Bahtsul Masa'il NU (hereinafter BM-NU) does not make the Al-Qur'an and Sunnah as the highest source of law; because BM-NU is of the opinion that the law of doing legal istinbath with the Qur'an directly - without going through the opinions of scholars who are deemed worthy and capable-is haram. In the 11th NU congress in Banjarmasin (9 June 1935) there were questions submitted to NU regarding establishing Islamic law directly referring to the Qur'an and 
Sunnah. The congress stipulates that the determination of the law by referring directly to the Qur'an and Sunnah without going through the books of figh, is not allowed; because the direct legal determination of the Qur'an and Sunnah will make those who do it astray (dhâl) and will also mislead others (mudhil) (Masyhuri, 1977:137). This decision seems to be the forerunner that triggers the birth of a number of BM-NU decisions that are different from other ulema's decisions regarding ways of enacting the law.

Obligation to follow one of the schools of jurisprudence

Along with the prohibition of deciding an opinion by referring directly to the Qur'an and Hadith, BM-NU stipulates that following one of the schools of figh is obligatory. In the 1st NU congress in Surabaya (21 October 1926) it was stipulated that Muslims must follow one of the four schools of jurisprudence. The reason is to follow the opinion of Sayyid 'Ali al-Khawas. Sayyid 'Ali al-Khawas-in his book al-Mîzân al-Sya'rani-argued that Muslims must follow one of the four schools of jurisprudence and the same opinion is also explained in the book Nihâyat al-Sûl (Mashuri, 1977:138).

Implicitly, the decision regarding the obligation to follow the four schools of jurisprudence is a thought-washing process (taqds al-afkâr) which does not seem to be in line with the rules adopted by NU, namely maintaining old opinions that are still useful and adopting new, more favorable opinions. useful (الحافظة لـ القدي الصالح الأخذ الجديد لخ) (Haidar, 1994:318).

Because of the decision regarding the obligation to follow one of the four schools of jurisprudence, BM-NU stipulates a number of technical terms that are part of a series in the legal decision-making process. These terms are: first, al-kutub al-mu'tabarat; namely books on Islamic teachings that are in accordance with the aqidah of Ahlusunnah Wal-Jama'ah (formula of the 27th NU Congress). Second, qawlî school; namely following the "finished" opinions within a certain school of thought. Third, manhâjî school; i.e. bermadzhab by following the way of thinking and the rules of determining the law drawn up by the imam of the madhhab.

Fourth, qawl and face. Qawl is the opinion of the madhhab imam; and the face is the opinion of the scholars of madhhab; and fifth, ilhâq al-masấil bi nazhâ'irihâ, which equates the law of a case or problem that has not been answered by the scholars in the book with similar problems that have been answered by the book (equating it with an opinion that has "made up"). 
Nature of BM-NU Decisions

In general, decisions or fatwas of Islamic organizations in Indonesia can be divided into two: first, decisions which are explicitly stated to bind all members of the mass organizations concerned so that they are "obligated" to follow the decision. In other words, the decision of the ulama (who is bound by the law or fatwa) regarding the law of something is binding. The decision of the Persis Hisbah Council is binding on the Persis congregation; and second, decisions that are not binding on all members of the mass organizations concerned so that they are not "obligated" to follow the decision. The decision of the Majlis Tarjih and the Development of Muhammadiyah Islamic Thought is not binding on Muhammadiyah members.

All BM-NU decisions taken with agreed procedures, whether carried out within the organizational structure or outside, have an equal position and do not cancel each other out; and a decision made by BM-NU is considered to have a higher binding power after being ratified by the NU Syuriah Executive Board without having to wait for the Ulama National Conference or Congress.

The nature of the BM-NU decisions at the National Conference and Congress levels are: (a) ratifying the draft decisions that have been prepared in advance; and (b) intended for decisions that are considered to have a broad impact in all fields. BM-NU does not provide affirmationexplicitly - in the form of a decision regarding the nature (binding or not of NU members) of its decision. However, the decision regarding the obligations of one of the four schools of figh can be used as the basis that the BM-NU decision binds NU citizens.

Qiyas and Ilhaq

One of the "new" treasures in the BM-NU legal decision-making method is ilhâq. Basically, ilhâq is a continuation of the qiyâs method or analogy. Linguistically, qiyâs means (التقدير التسوية), guessing and equating (Mahmasahshani 1961:165; al-Khinn, 1982:470). The linguistic understanding of qiyâs which is closer to the linguistic understanding of qiyâs is to equate the branch to the main (تسوية الفرع الى الأصل) (Al-Hakim, 1963:304; Al-Shafi'i, t.th.: 
205). While the definition of qiyâs in terms is explained by scholars with different editors.

Al-Qadhi Abi Bakr said that what is meant by qiyâs is (مل لوم لـ لوم ائبات ( لمما أو لمها أمر امع ا حكم اؤ (Al-Khinn, 1982:470; Al-Juwaini, 1400:745); “bringing something that is known to something else that is also known to establish a law or prohibit both because there is something in common between the two, both law and nature."

Al-Amidi said that what is meant by qiyâs is ( عبارة الاءستواء الفرع والأصل العلة (المستنباط الأصل (Al-Khinn, 1982:470); "equating the branch with the principal on the basis of the "llat of the principal law." Ibn al-Hajib explained that what is meant by qiyâs is (مساوة لأصل لة) (Al-Khinn, 1982:471); "equalizes branch law to principal because of the similarity of 'illat law."

Not all definitions are agreed upon by other scholars. Regarding the first definition put forward by al-Qadhi Abi Bakr, Imam al-Ghazali in alMankhûl min Ta'liqât al-Ushl said that this definition includes fasid, because the term al-jâmi' used is majhûl (cryptic) (Al-Ghazali, 1980:323).

Almost the same as the definitions above, Ali Hasab Allah explained that what is meant by qiyâs is (مشار كة عنه لمنصوص لـ الشرعي لة ا الحكم) (Hasaballah, 1971:124); "equating the law of something (which is not specified in the texts) with something else (whose law has been determined in the texts) on the basis of "illat Hukum."

Although explained by different editors, almost all of the definitions put forward have explained about al-qiyâs as an effort to determine laws that are not legally stipulated in the texts by equating them to something else that already has laws in the texts; and they take 'illat as a standard.

Thus, there are four pillars of qiyâs: First, the principal (al-ashl or almaqîs 'alayh) is the legal provision of something contained in the text. Second, the branch (al-far 'or al-maqis) is a particular topic or case for which the legal provisions are not determined in the texts. Third, the law (alhukm), namely the provisions regarding the permissibility and impermissibility of doing or consuming something; and fourth, al-illat, namely the "cause" of the law understood by scholars from the texts; 
whether 'illat is contained in the texts explicitly (called 'illat manshûshat) or is it obtained after doing in-depth research ('illat munstanbâthat).

An example of qiyâs is regarding the law of consuming shabu-shabu or marijuana. Cannabis or methamphetamine is a branch (al-far' or al-maqîs); khamr is the principal (ashl or maqîs 'alayh); the law is haram; and the forbidden illat is al-iskar (intoxicating).

The difference between qiyâs and ilhaq lies in the pillars. Ashl in qiyas is a provision that is in the Qur'an and Sunnah. Therefore, a branch cannot be used as asl in doing qiyâs. However, making a branch as ashl is permissible in ilhaq. An example that makes things easier is zakat fitrah. The law of zakat fitrah is obligatory for those who can afford it which is explicitly specified in the Hadith. The object that must be removed is dates or wheat. Why should it be dates or wheat? One answer is that dates and wheat were staple foods at that time. Therefore, the ulama determined that dates and wheat could be replaced with rice (because the staple food of the Indonesian people is rice). Thus, the permissibility of doing zakat fitrah with rice is the result of an analogy. His illat is a staple food.

In a certain period of time, paying zakat with rice is considered less practical. A more practical zakat expenditure is using money. Therefore, the next idea emerged from some scholars, namely zakat does not have to use rice, but can be with money. The amount of money that must be spent is commensurate with the price of rice that must be spent. The replacement of dates and wheat with rice is called qiyâs; and replacing rice with money is called ilhaq.

If ilhâq is not possible because there is no mulhaq bih and wajh al-ilhâq at all in the mu'tabar books, legal istinbath is carried out in a congregational manner by practicing qawâ'id al-ushûliyyat and qawâ'id al-fighiyyat by the experts. However, the limits or criteria for measuring experts or not in conducting ijtihad, have never been discussed.

Mu'tabar books

In line with the prohibition of establishing law directly on the main source, the Qur'an and Sunnah, BM-NU stipulates a number of figh books that can be used as references in determining the law. Until this article was written, detailed information has not been obtained regarding the books 
(and their authors) which are included in the $m u^{\prime}$ tabar books. However, implicitly, the books that are considered $m u^{\prime}$ tabar are books that are used as references by the BM-NU in determining the law on a number of topics. K.H. Abdul Aziz Masyhuri (Deputy Rais Syuriah PWNU East Java) wrote that there were 162 figh books used as references by BM-NU in establishing laws. Among these are the books of Ersyâd al-'Ibâd by al-Malibari, I'ânat alThâlibîn by Abu Bakr Syatha, al-Adzkâr by al-Nawawi, and Bughyat alMustarsyidîn by Sayyid 'Abd al-Rahman (Masyhuri, 1982: 405-413).

As one of the impacts of the determination of mu'tabar books by BMNU, is that the Ministry of Religion (in 1953) has determined 13 books to be used as guidelines in deciding cases in courts within the Religious Courts, namely: (1) al- Bâjâr; (2) Fath al-Mu'în; (3) Syarqawî 'alâ al-Tahrîr; (4) alMahalli; (5) Fath al-Wahhab; (6) Tuhfat; (7) Tagrîb al-Musytâq; (8) Qawânin alSyar'iyyat Uthman Ibn Yahya; (9) Qawânin al-Syar'iyyat Sadaqat Di'ân; (10) Shamsûrî fí al-Farầidh; (11) Bugyat al-Murtasyidn; (12) al-Fiqh 'alâ Madzâhib alArba'at; and (13) Mugnî al-Muhtâj (Arifin, 1985:27; Mubarok, 1995:103).

Kitab al-Bâjûrî (Hâsiyat al-Bâjûrî) by Ibrahim Ibn Muhammad al-Bajuri (d. 918 H./1512 AD) (2 vols) is a commentary on the book Fath al-Qarîb by Abu Abdullah Muhammad Ibn Qasim al-Gazzi (w. 918 H./1512 AD); and the book Fath al-Qarîb is a commentary on the book Mukhtashar by Ahmad Ibn al-Hasan Ibn Ahmad al-Isfahani (Qadhi Abu Shodya) (d. 600 H./1203 AD) (Steenbrink, 1984:155). So, the book of al-Bâjûrî is a commentary on the book of Fath al-Qarîb; and the book Fath al-Qarîb is a commentary on the book Mukhtashar.

Zayn al-Din al-Haytami's book Fath al-Mu'în (d. 973 H./1465 H.) is a commentary on Ibn Hajar al-Haytami's Qurrat al-'Ayn bi Muhimmat al-Dn. The book Fath al-Mu'în bi Syarh Qurrat al-'Ayn by Zayn al-Din Ibn 'Abd al'Aziz al-Malibari is commented on again by Muhammad Syatha alDimyathi. Muhammad Syatha al-Dimyathi's commentary on the book Fath al-Mu'în is entitled I'ânat al-Thâlibîn. Shidqi Jamil al-'Athar commented on the book I'ânat al-Thâlibîn by Muhammad Syatha al-Dimyathi with the title Hâsyat I'ânat al-Thâlibin. Thus, the first book is the Qurrat al-'Ayn bi Muhimmat al-Din by Ibn Hajar al-Haytami; the commentary on the Qurrat al'Ayn is Fath al-Mu'în; the commentary on the book of Fath al-Mu'în is I'ânat al-Thâlibîn; and the commentary on the book I'ânat al-Thâlibîn is Hâsyat I'ânat al-Thâlibîn. 
The book of Fath al-Wahâb by Abu Yahya Zakaria Ibn Muhammad alAnsari (d. 926 H./1520 AD) is a commentary on the book Minhaj al-Thâlibîn by Abu Zakaria Yahya Ibn Sharaf al-Nawawi (d. 676 H./1277 M.); and the book Minhaj al-Thâlibîn is also a commentary on the book al-Muharrar by Abu al-Qasim Abd al-Karim Ibn Muhammad al-Rafi'i (d. 623 H./1226 AD). Likewise the book of al-Mahalli by Jalal al-Din Muhammad Ibn Ahmad alMahalli (d. 864 H./1460 H.) and the book of Tuhfat al-Muhtâj by Ibn Hajar al-Haytami (d. 973 H./1465 AD). ) is a commentary on the book Minhâj alThâlibîn by Abu Zakaria Yahya Ibn Syaraf al-Nawawi (Steenbrink, 1984:155).

The figh books are studied in Islamic boarding schools in Indonesia. According to M. Atho Mudzhar, the figh books can be grouped into four families: First, the figh books that lead to the book of al-Muharrar by Imam al-Rafi'i are: (1) Minhâj al-Thâlibîn by Imam Nawawi ( w. 576 H); the book of minhâj was then abridged (ikhtishâr) by Mahalli (d. $864 \mathrm{H}$ ) into Kanz alRâghibîn; then Kanz al-Râghibîn was commented on (syarh) by Qalyubi and 'Umairah became Sharh Kanz al-Râghibîn; (2) Manhâj al-Thullâb by al-Ansari (d. 926 H); (3) Fath al-Wahhab by al-Ansari; (4) Tuhfat al-Muhtâj by Ibn Hajar (d. 973 AD); (5) Mughnî al-Muhtâj by al-Syarbini (d. 977 H); and (6) Nihayat al-Muhtâj by al-Ramli (d. $926 \mathrm{H})$.

Second, the fiqh books that lead to the book of Taqrîb by Abu Syuja' are: (1) al-Iqnâ' by al-Syarbini (d. 977 H); (2) Kifâyat al-Akhyâr by al-Dimasyqi (d. 829 H); (3) Fath al-Qarîb by Ibn Qasima 1-Ghuzzi (d. 918 H); (4) Taqrîr by Awwad; (5) Tuhfat al-Habîb by Bujairimi (d. $1110 \mathrm{H})$; and (6) Hâsiyat al-Bâjûrî by al-Bajuri (d. $1277 \mathrm{H})$.

Third, the figh books that lead to the book Muqaddimat al-Hadhramiyyat by Ba Fadhal (10th century H / XV century AD) are: (1) Minhâj al-Qawwim by Ibn Hajar al-Haitami (d. 1338 H/1919 M); (2) Busyrâ al-Karîm by Sa'id Ibn Ba'syin; and (3) al-Hawasyi al-Madaniyyat by Sulaiman al-Kurdi (d. 1194 $\mathrm{H} / 1780 \mathrm{AD})$.

Fourth, the figh books that lead to al-Malibari's Qurrat al-'Ayn (d. $975 \mathrm{H})$ are: (1) Al-Malibari's Fath al-Mu'în; (2) Nihayat al-Zayn by al-Nawawi alBantani (19th century AD); (3) I'ânat al-Thâlibîn by al-Dimyathi $(1130 \mathrm{H})$; and (4) Tarsyîh al-Mustafidîn by 'Alwi al-Tsaqqaf (1130 H) (Mudzhar, 2000:109).

Problem Analysis Framework 
In determining the law of a problem, BM-NU uses the following problem-solving framework: First, it examines the factors that cause the problem from an economic, cultural, political, and social perspective.

Second, an analysis of the impacts (positive and negative) caused by a problem that is being sought for law in terms of economics, culture, and politics. Third, legal analysis (fatwa [including figh, pen.] about the problem being resolved). After considering the background and its impact in various fields. In addition to the formal juridical-fiqhi decisions, the decisions also take into account the considerations of figh and positive law which include: (a) legal status (al-ahkâm al-khamsat); (b) the basis of the teachings of Ahlus Sunnah wal-Jama'ah; and (c) positive law.

Fourth, analysis of actions, roles and supervision of what must be done as a consequence of decisions or fatwas. Then BM-NU determines the party who can carry out monitoring, the method, time, place, and monitoring mechanism, so that decisions can proceed according to plan.

The channels used to carry out monitoring are: (a) political channels (trying on the lines of state authority with the aim of influencing government policies); (b) cultural channels (trying to generate public understanding and awareness through various mass media and forums such as recitations); (c) the economic route (improving people's welfare); and (d) social pathways (efforts to improve public health, and the environment).

\section{Legal Enforcement Procedure}

In general, the problems that BM-NU intends to solve can be divided into four categories: first, problems that have been solved by scholars who have written in $m u^{\prime}$ tabar books and the opinion is uniform; second, problems that have been resolved by scholars who have written in mu'tabar books, but in these books there are various opinions; third, problems that have not been resolved by scholars so that there is no scholarly opinion in the mu'tabar books at all, but it is possible to do ilhaq; and fourth, problems that have not been resolved by the scholars so that there is no information about their opinions in the mu'tabar books, and there is also no wajh.

The identification and division of these problems gave birth to different steps for determining legal decision-making: first, problems that have been resolved by scholars who have been written in mu'tabar books 
and the opinions are uniform, are resolved by quoting opinions. and followed as is.

Second, problems that have been resolved by scholars who have written in mu'tabar books, and in these books there are various opinions, are resolved by means of taqrir jama'i (mutual agreement) to choose one opinion (qawl).

Third, problems that have not been resolved by scholars so that there is no opinion of scholars in mu'tabar books, and in mu'tabar books there is wajh, resolved by ilhâq; and fourth, if ilhâq cannot be done, then the last step is to do ijtihad (istinbâth al-ahkâm) together (jama'i) with a manhâjî madhhab procedure.

\section{Opinion Selection Procedure (Taqrîr Jamâ'î)}

As a continuation of the procedure for determining the law, BM-NU distinguishes the opinions of scholars contained in the mu'tabar books into six: (1) opinions agreed upon by al-Shaykhânî (al-Nawawi and Rafi'i); (2) the opinion held by al-Nawawi only; (3) the opinion held by al-Rafi'i only; (4) the opinion supported by the majority of scholars; (5) the opinion of the smartest scholars; and (6) the opinion of the most sane scholars'.

As mentioned earlier that BM-NU requires its members to follow one of the four schools of jurisprudence; and in practice, BM-NU is more likely to quote the opinions of clerics who adhere to the madzhab - not the opinions of the founding clerics of the madzhab. If several opinions are found-in $m u^{\prime}$ tabar books - when trying to decide the law of a problem, BM-NU chooses one opinion among the various opinions. The selection of opinions is carried out by prioritizing (1) the opinion agreed upon by al-Shaykhânî (al-Nawawi and Rafi'i); (2) the opinion held by al-Nawawi only; (3) the opinion held by al-Rafi'i only; (4) the opinion supported by the majority of scholars; (5) the opinion of the smartest scholars; and (6) the opinion of the most sane scholars'. Thus, the sorting of opinions carried out by BM-NU shows levels or is understood hierarchically.

\section{CONCLUSION}


BM-NU has its own legal istinbath framework which is different from the legal framework of the previous scholars-such as the legal istinbath framework proposed by Abu Hanifah and Muhammad Ibn Idris al-Syafi'i, also different from the legal istinbath framework. with other Indonesian Islamic organizations - such as the legal istinbath framework of the Hisbah Persis Council and the legal istinbath framework of Majlis Tarjih and the Development of Muhammadiyah Islamic Thought. In general, the legal istinbath framework adopted by BM-NU tends to present themselves as muttabi' ulama and do not present themselves as mujtahid scholars. Therefore, BM-NU assigns a ranking of ulama's opinions in order to choose one opinion among the existing ulama's opinions; and ijtihad is only carried out if the problem to be solved is not found by the qawl and his face in the mu'tabar books.

\section{REFERENCES}

Abu Dawud, Sunan Abi Dawud, Bandung: Dahlan, t.th.

Abu Zahrah, Muhammad, Muha-dharat fi al-Tarikh al-Madzahib al-Fiqhiyyat, Mesir: Jam'iyah al-Dirasah al-Islamiyah, t.th. , Ushul al-Figh, Beirut: Dar al-Fikr al-'Arabi, t.th.

Arifin, Bustanul, "Kompilasi: Fiqh dalam Bahasa Undang-undang" dalam Pesantren, Nomor 2/Volume II/1985.

Dzarwi, Ibrahim Abbas, al-, Teori Ijtihad dalam Hukum Islam, Semarang: Dina Utama, 1983.

Ghazali, Abu Hamid Muhammad Ibn Muhammad, al-, al-Mankhul min Ta'liqat al-Ushul, Damaskus: Dar al- Fikr, 1980. , al-Mustashfa min 'Ilm al-Ushul, Beirut: Dar al-Fikr, t.th.

Haidar, M. Ali, Nahdatul Ulama dan Islam di Indonesia: Pendekatan Fikih dalam Politik, Jakarta: PT. Gramedia Pustaka Utama, 1994.

Hakim, Muhammad Taqiy, al-, al-Ushul al-'Ammat li al-Figh al-Muqarin, Beirut: Dar al-Andalus, 1963.

Hamadani, Abd al-Jabbar, al-, Syarh al-Ushûl al-Khamsat, Kairo: Maktabah Wahbah, 1965, ditahqiq oleh 'Abd al-Karim Utsman.

Hasab Allah, Ali, Ushîl al-Tasyrî̀' al-Islâmî, Mesir: Dar al-Ma'arif, 1971.

Juwaini, Imam al-Haramayn, al, al-Burhan fi Ushul al-Figh, Kairo: Dar alAnshar, $1400 \mathrm{H}$. 
Khalaf, Abd al-Wahhab, 'Ilm Ushûl al-Figh, Mesir: t.pn, t.th.

Khinn, Mushthafa Sa'id, al-, Atsar al-Ikhtilâf fî al-Qawấ'id al-Ushûliyyat fì Ikhtilâf al-Fuqahâ, Beirut: Mu'assasah al-Risalah, 1982.

Mahmasahshani, Subhi, Falsafat al-Tasyri' al-Islami, Beirut: Dar al-Ilm li alMalayin, 1961.

Masyhuri, K. H. Abdul Aziz, Masalah Keagamaan: Hasil Muktmar dan Munas Ulama Nahdhatul Ulama, Surabaya: PP. Rabithah Ma'ahadil Islamiyah dan Dinamika Press, 1977.

Mubarok, Jaih, Metodologi Ijtihad Hukum Islam, Yogyakarta: UII Press, 2002. - Pemikiran al-Thahthawi tentang Ijtihad dan Perwujudannya dalam Figh, Jakarta: Program Pascasarjana IAIN Syarif Hidayatullah, 1998.

, "Dinamika Pemikiran Hukum Islam di Indonesia" dalam Unisia: Jurnal Ilmu-ilmu Sosial, Nomor 48/XXVI/II/2003.

, Tadrij sebagai Prinsip Pembentukan Hukum Islam dan Penerapannya di Indonesia, Jakarta: PPs IAIN Syarif Hidayatullah, 1995.

- Sejarah dan Perkembangan Hukum Islam, Bandung: PT. Remaja Rosdakarya, 2000.

Mudzhar, M. Atho, Membaca Gelombang Ijtihad: Antara Tradisi dan Liberasi, Yogyakarta: Titian Ilahi Press, 2000.

Nurrohman, "Metode Istimbath Hukum Majlis Bahtsul Masail Nahdhatul Ulama" dalam Madzhab: Jurnal Pemikiran dan Hukum Islam, Volume 1, Nomor 1, April 2004.

Steenbrink, Karel A., Beberapa Aspek tentang Islam di Indonesia Abad Ke-19, Jakarta: Bulan Bintang, 1984.

Syafi'i, Muhammad Ibn Idris, al-, al-Risalaț, Jakarta: Dinamika Berkah Utama, t.th.

Ulwani, Thaha Jabir Fayadh, al-, Adab al-Ikhtilaf fi al-Islam, Washington: USA: al-Ma'had al-'Alami li al-Fikr al-Islami, 1987.

Umari, Nadiyah Syarifah, al-Ijtihad fi al-Islam: Ushuluh-Ahkamuh-Afatauh, Beirut: Mu' assasah al-Risalah, 1984.

Zuhaili, Wahbah, al-, Ushul al-Figh al-Islami, Beirut: Dar al-Fikr, 1986. 
